\title{
An overview on properties and internal characteristics of anaerobic bioreactors of food
} waste

\begin{abstract}
Recently, achieving to a cost-effective method of treating industrial wastes with maximum level of removing contaminant and microorganism has been researched by many scientists. Anaerobic bioreactors are important tools and platforms in biological and microbiological technology to manage such kind of huge quantity waste. Today is widely used in purification of factories' waste due to their being low energy consumption. In this review article, benefits and defects of anaerobic process and 3 main properties of bioreactors i.e. uniformity, instability of time and location reviews. In order to increase the efficiency, parameters of waste refining like temperature, $\mathrm{pH}$, retention time, organic loading rate and reproduction of bacteria are calculated and controlled. Internal parts can improve retention time even mass transfer.
\end{abstract}

Keywords: bioreactor, anaerobic digestion, industrial waste, biotechnology, purification

\author{
Volume 8 Issue 4 - 2018 \\ Muhammad Usman Khan,' Sofien Chniti, ${ }^{2}$ \\ Mustafa Nadhim Owaid, ${ }^{3}$ Muhammad Bilal \\ Hussain ${ }^{4}$ Mohammad Ali Shariati ${ }^{5}$ \\ 'Department of Energy Systems Engineering, Faculty of \\ Agricultural Engineering and Technology, University of \\ Agriculture, Pakistan \\ 2University of Rennes I, France \\ ${ }^{3}$ Al-Athar School, Heet Education, Iraq \\ ${ }^{4}$ Faculty of Science and Technology, Government College \\ University, Pakistan \\ ${ }^{5}$ Orel State University, Russia
}

\begin{abstract}
Correspondence: Mohammad Ali Shariati, Associate Senior Researcher, Laboratory of Biocontrol and Antimicrobial Resistance, Orel State University named after I.S. Turgenev, Russia, Email shariatymohammadali@gmail.com
\end{abstract}

Received: June 14, 2018| Published: August 31, 2018

\section{Introduction}

Since a large amount of food resources comes to waste when are processing in the factories, recently more attention is being targeted to use anaerobicdigestion. ${ }^{1}$ Currently, huge amount of organic waste is generated including forest, wood industries, human, animal and agricultural crops. Furthermore they saved solar energy in different forms. This saved energy can be harvested by many ways like biochemical conversion, thermochemical conversion etc and may release $\mathrm{CH}_{4}, \mathrm{H}_{2}, \mathrm{CO}, \mathrm{CO}_{2}$ etc. Treatment of food waste is carried out in a single phase anaerobic digestion chamber in which decomposition of waste arises from anaerobic microorganism. ${ }^{2}$ Anaerobic digestion is an advantageous way of waste treatment in which both recycling energy and control of contamination in consideration. Anaerobic digestion is defined as the decomposition of biomass by active micro flora in absence of oxygen. Till date, several methods biological treatments and the study results related to organic materials were available. Comparison between aerobic and anaerobic processes shows that later is more usable in treatment due to its low-energy consumption and produced final waste. Therefore, anaerobic processing of industrial wastes with toxic compounds and domestic waste has been showing upwards trends. Achieving the ability of environmental protection and anaerobic treatment along with bioreactors have been taken in consider recently. ${ }^{3}$

Figure 1 illustrates the process where the first two steps are operating within defined parameters ensures optimal biogas production. The process of anaerobic digestion is simple. Different kinds of digester structures are being used all over the world like, floating drum type biogas plants, fixed dome type biogas plants, bag type biogas plants etc. Simply, a digester constitutes of digestion chambers, an entrance, and exit part. Biogas entraps by means of Dom-like part and flows through gas outlet. Invention of bioreactors came back to the year 1859 in Mumbai, India. In 1930s, the anaerobic digestion process found it's scientific basis. Indeed, sterile tanks are the first generation of bioreactors. In late 1970s, up-flow waste introduction, considered as the second generation of bioreactors. ${ }^{4}$ Digestion of food waste involves two methods; batching and continuous. Former includes the addition of waste in to a vessel followed by sealing as anaerobic digestion is preceded. Some unfirming tools also are available to integrate composting of remained products. Later is more common with a continuous flow of feedstock where their entrance to vessel is constantly.

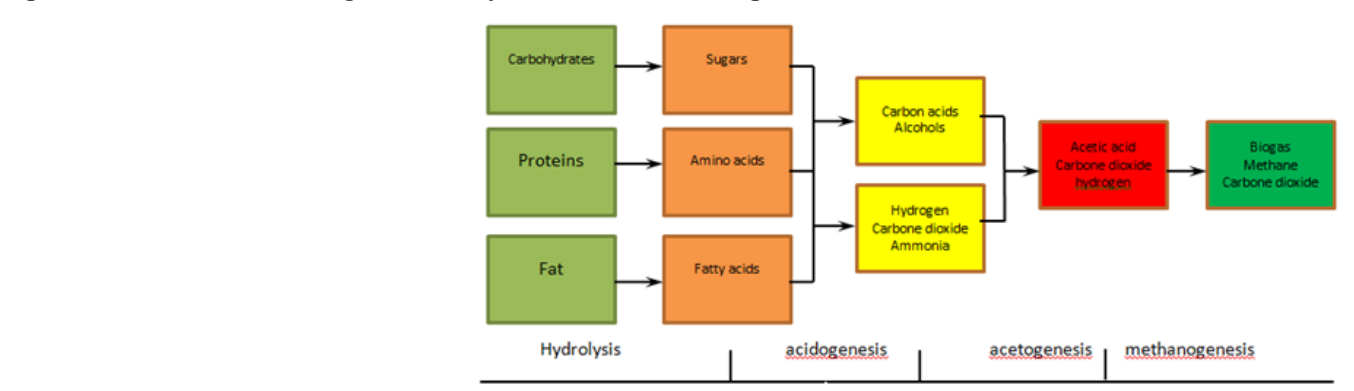

Figure I Anaerobic digestion process. ${ }^{17,18}$ 
Generally, biogas microbes exist in three kinds of ecological environments where methane is formed; 1) biogas fermentation in complex organic materials like human and animal waste. In such an environment organic materials undergo the whole process of biogas fermentation, i.e., three stages, before they are finally converted into methane; 2) biogas fermentation in human and animal digestive tracts and the rumens of hervivorous animals. In such an environment there are only two stages in the conversion of organic substances into methane: hydrolysis and methanogenesis; 3 ) the formation of methane by the geochemical process. Hot springs or hot water heated by an active undersea volcano also provides an ecological environment for biogas microbes. We have restrained methanogenesis in case of an anaerobic digester where waste of harvested feedstock places into a reactor, and then methanogenic bacteria are inoculated to produce methane. Unilke landfilling and anaerobic composting, anaerobic digestion needs a prerequisitment of of higher control of Corbone footprint in its resulted fugitive emissions. ${ }^{5}$ In general, four major steps involved in production of methane; 1) hydrolysis, 2) acidogenesis; 3) acetogenesis and 4) methanogenesis and can occur during the entire stages of these mechanism either simultaneously or interdependent.

\section{Benefit and defect of anaerobic bioreactors}

Anaerobic digestion is a proven method for production of biogas with the ability of generating both heat and electricity. The principles of anaerobic treatment are the use of biomass to convert organic materials or consumable oxygen $\left(\mathrm{O}_{2}\right)$ to methane gas in absence of $\mathrm{O}_{2}$. First stages of anaerobic granules follow the same principles in production of biofilm on solid bed. Most researchers believe that Methanosaetaconcilii has a key role introduction of granules. When a system is in exchange, bacteria rapidly consume intermediate acidic compounds. However, in case of not sufficient population of methane bacteria cause to increase the concentration of volatile compounds. Therefore, reduction of acid amount reveals that methane creators are not in balance with acid creators. Classifying of bacteria depends on temperature; Psychrophilic, mesophile and thermophile. ${ }^{6}$

\section{Properties of anaerobic bioreactors}

Non uniform system: anaerobic reactors act as a non-uniform system i.e. anaerobic treatment performs in 3 different phase including solid (sludge), liquid (waste liquor) and gas (methane). Solid phase: solid phase involves sludge granules with $0.5-2 \mathrm{~mm}$ diameter which is located in the lowest part of reactor and include a group of bacteria act in up-flow waste with no supportive networks. Therefore, creates good conditions for bacteria to contact each other and have the possibility of starting growth. Liquid phase: liquid phase flows upward via a sludge bed in the lowest part of reactor. Collecting of 3 phases of biogas along with internal recycler of sludge facilitate the flow through releasing bubbles of up-flow sludge particles. ${ }^{7}$ Gas phase: biogas refers to produced gas during decomposition of organic materials such as animals and plants wastes; organic waste came from industries and domestic cases in absence of oxygen.

\section{Time instability}

Bioreactor used to treat waste which is a complex of complicated organic materials. Industrial waste has made it facing challenges in different conditions of production such as temperature, $\mathrm{pH}$ with a different range in four seasons. ${ }^{8}$ Due to some limitations related to the technology of anaerobic treatments, scientist and engineers are trying to make some advancement to make this technology compatible to climatic conditions and type of waste. Treating of small sewages individually perform in a central established place in cities. But anaerobic treatments successfully decrease clostridium perfirngens but not as much as salmonella, E. coli under the acceptable level, therefore the end product is not able to pass the least acceptable level of European rules. ${ }^{9}$

\section{Instability of space}

The conversion of complex organic materials to biogas involves some series of reactions. First stage is the formation of low chain fatty acids. Final stage is production of methane mainly by converting of acetic acid and hydrogen to methane and Carbone dioxide. The first stage of process is hydrolysis. This stage is very important to anaerobic digestion that is why fermenting microorganism may not directly participate in processes. Therefore, dissolved complicated solution like cellulose is converted to sugars, amino acids, fatty acids. Complicated polymer substance hydrolyses to monomer. For instance, cellulose is converted to sugars, alcohols \& protein to amino acids using microbial enzymes including lipase, protease, cellulose, and amylase. The second equation is an example of hydrolysis reaction shows the conversion of polysaccharide to glucose. Hydrolysis involves the following reactions;

$$
\text { Lipids } \rightarrow \text { Fatty Acids }
$$

$$
\begin{gathered}
\text { Polysaccharides } \rightarrow \text { Monosaccharides } \\
\text { Protein } \rightarrow \text { Amino Acids } \\
\mathrm{C}_{24} \mathrm{H}_{40} \mathrm{O}_{20} \mathrm{H}_{2} \mathrm{O}+3 \mathrm{H}_{2} \mathrm{O}_{4} \mathrm{C}_{6} \mathrm{H}_{12} \mathrm{O}_{6}
\end{gathered}
$$

In the second stage fermentation takes place. Acidogenic bacteria convert sugars and amino acids to $\mathrm{CO}_{2}, \mathrm{H}_{2}$ and organic acid. The main products of acidogenesis are acetic acid, propionic acid, butyric acid and ethanol. In a moderate system, most organic materials are easily used by methanogenic microorganisms and converted to acetate, hydrogen and carbon dioxide. Thirty percent of products include short chain fatty acids and alcohols. Among these products, hydrogen, carbon dioxide \& acetic acid would not transfer to the third stage and are directly used by methanogenic bacteria. Equations 2, 3, and 4 are routine acidogenesis reactions in which glucose is converted to ethanol, propionate, and acetic acid.

$$
\begin{aligned}
& \mathrm{C}_{6} \mathrm{H}_{12} \mathrm{O}_{6} \rightarrow 2 \mathrm{CH}_{3} \mathrm{CH}_{2} \mathrm{OH}+2 \mathrm{CO}_{2} \\
& \mathrm{C}_{6} \mathrm{H}_{12} \mathrm{O}_{6}+2 \mathrm{H}_{2} \rightarrow 2 \mathrm{CH}_{3} \mathrm{CH}_{2} \mathrm{COOH}+2 \mathrm{H}_{2} \mathrm{O} \\
& \mathrm{C}_{6} \mathrm{H}_{12} \mathrm{O}_{6}+2 \mathrm{H}_{2} \mathrm{O} \rightarrow 2 \mathrm{CH}_{3} \mathrm{COOH}+2 \mathrm{CO}_{2}+4 \mathrm{H}_{2}
\end{aligned}
$$

In third stage, acetogenic acid converts the products of second stage along with acidogenesis products to acetic acid, $\mathrm{CO}_{2}$ and $\mathrm{H}_{2}$. The fourth stage shows the conversion of propionate to acetate in low pressures. Glucose and ethanol converted to acetate within third stage. Methanogenesis is the final step in biogas production process. Fusion of acetic acid produces $\mathrm{CO}_{2}, \mathrm{CH}_{4}$. Production of methane is accomplished mostly via reduction of $\mathrm{CO}_{2}$. But decreasing the concentration of hydrogen leads to acetate reaction, considered as the main reaction of methane production. Methanogenic bacteria include Methanobacterum, Methanobacillus, and Methnosarcina. Methanogens are categorized into two groups; consumers of acetate and hydrogen/ carbon dioxide:

$$
\mathrm{CO}_{2}+\mathrm{CH}_{4} \mathrm{CH}_{4} \longrightarrow \mathrm{CH}_{4}+2 \mathrm{H}_{2} \mathrm{O}
$$

Reduction of carbon dioxide takes place as provided below:

$$
\mathrm{CO}_{2}+\mathrm{CH}_{4} \mathrm{CH}_{4} \longrightarrow \mathrm{CH}_{4}+2 \mathrm{H}_{2} \mathrm{O}
$$


However, the use of this method is limited due to low amount of methane production and instability of the process. Interesting studies have been performed to determine the mechanism control and preventive factors. Methane producing bacteria are obligate aerobes and have low amount of oxygen, which is harmful for them. Nitrogen is a key nutrient for anaerobic microorganisms. The concentration of ammonium must be maintained at $40-70 \mathrm{mg} / \mathrm{L}$ in order to prevent reduction of biomass activity. ${ }^{10}$

\section{Parameters on anaerobic reactors}

Decomposition of compounds or unwanted contaminant depends on some factors. The main parameters related to reactors include temperature, $\mathrm{pH}$, organic loading rate, the flow rate and distribution of particle sizes.

Temperature: is an important physical factor affecting the chemistry of water as well as all processes related to treatment of water for example:

i. Treating of biological wastes: Cool water reduces the efficiency of filter to $30 \%$. Lower temperatures prevent nitrification.

ii. Digestion: The least retention time varies from 2 days at $35^{\circ} \mathrm{C}$ up to 10 days at $20^{\circ} \mathrm{C}$. The minimum temperature needed for digestion depends on ambient temperature.

iii. Microbial growth: Temperature affects variety of population of bacteria.

iv. Low temperature: Affects internal and external environment of a bacterial cell. Additionally, low Temperatures are it used as an additive in conversion processes.

v. In case of low temperatures, consumed time may be longer; however, it can finalize by means of inculcation or digested sludge.

High temperature: The trend of activation in higher temperatures is rapid. Therefore, production processing occurs more efficiently. The digestion process shows more advantages such as, higher metabolic rates; special growth rates are much more in consequence. However, the death rate is more frequently compared to mesophiles. Therefore, the requirements to higher temperatures to keep mentioned conditions are considered as a restricting parameter and thus mostly these methods more follow through mesophilic conditions.

pH: Overall, methanogens are more active in neutral or acidic $\mathrm{pH}$ ranges.

Hydraulic retention time: The amount of average time of a solute which remains in a reactor.

Organic loading rate; Organic loading time: A group of bioreactors like those equipped with internal rotation system, reactors with anaerobic liquid bed etc are able to load with $40 \mathrm{~m}^{3} \mathrm{~d} / \mathrm{cod}$. Sludge retention time: this parameter is used as critical parameters on determination of physiochemical properties so that as much sufficient as the time is, methanogenic activity performs more effectively.

The flow rate: Increasing of rate from $1.6 \mathrm{~m} / \mathrm{h}$ to $3.2 \mathrm{~m} / \mathrm{h}$ led to loss of efficiency from $55 \%$ to $50 \%$ shows the role of entrapping and absorbing. ${ }^{3}$

Distribution of particle size: Distribution of a powder particle size, granule material or dispersed particles in a liquid depends on a mathematical function in which rational amount generally determines presence of particles based on mass.

\section{Biochemical phenomenon of anaerobic digestion}

In the absence of electron receptors contribute in decomposing some polymeric substrates. ${ }^{11}$ Digestion begins with activities of a group of fermenting bacteria in which primary proteins and polysaccharides including organic materials in domestic sewages, alcohols and fatty acids, are facilitated. ${ }^{12}$ Fermentation of most monomers by enzymes and other non-hydrolytic fermentative bacteria leads to generation of acetate, methanol, hydrogen and oxygen. ${ }^{13}$ This fermenting activity is known as acidogenesis in which all the substrates are converted into $\mathrm{H}_{2}, \mathrm{CO}_{2}$.

\section{Other microbial groups in anaerobic digestion sulfite reducing bacteria}

In absence of sulfate, sulfite or thiosulfate, sulfite reducer bacteria grow lithotrophically and heterotrophically on different types of substrates and are the main micro flora of an anaerobic digester (Figure 1). Sulfite reducing bacteria are a group of obligate anaerobic bacteria that able to use hydrogen and many other organic compounds as the final electron receptor. The problem related to anaerobic digestion of sulfite is competition among sulfite reducing bacteria and other species of bacteria in presence of sulfite which leads to production of hydrogen sulfite instead of methane. ${ }^{14}$

This competition is beneficial for sulfite reducing bacteria owing to thermodynamic issues but the real output is different. Some of the main problems related to sulfite reducing bacteria are provided below:

i. Reduction of produced methane

ii. Inhibition of formation of $\mathrm{H}_{2} \mathrm{~S}$ on most trophic groups related to anaerobic digestion therefore reduction of reactor efficiency. ${ }^{15}$

iii. Corrosion of parts such as tubing, pumps. ${ }^{16}$

\section{Conclusion}

Anaerobic process is a stable efficient route for biogas (methane) production from which heat and electricity generation is possible. Regarding the fact that, successful production of each biotechnological end product depends on the amount of live micro flora and their growth in reactors, therefore the special designing is one of these critical system requirements.

\section{Acknowledgements}

None.

\section{Conflict of interest}

The authors declare that there is no conflict of interest.

\section{References}

1. Wei W. Anaerobic Co-digestion of Biomass for Methane Production: Recent Research Achievements. 2013;1-10

2. Demirel B, Scherer P, Yenigun O, et al. Production of Methane and Hydrogen from Biomass through Conventional and High-Rate Anaerobic Digestion Processes. Critical Reviews Environ Sci Techno. 2010;40(2):116-146.

3. Aiyuk S, Forrez I, De Kempeneer L, et al. Anaerobic and complementary treatment of domestic sewage in regions with hot climates--A review. Biores Technol. 2006;97(17):2225-2241.

4. Fermentation (biochemistry) From Wikipedia, the free encyclopedia. 
5. Levis JW, Barlaz MA, Themelis NJ, et al. Assessment of the state of food waste treatment in the United States and Canada. Waste Manag. 2010;30(89):1486-1494

6. Chan YJ, Chong MF, Chung LL, et al. A review on anaerobic-aerobic treatment of industrial and municipal wastewater. Chem Eng J. 2009;155(12):1-18.

7. Hulshoff Pol LW, de Castro Lopes SI, Lettinga G, et al. Anaerobic sludge granulation. Water Res. 2006;38(6):1376-1389.

8. Chong S, Sen TK, Kayaalp A, et al. The performance enhancements of upflow anaerobic sludge blanket (UASB) reactors for domestic sludge treatment A State-of-the-art review. Water Res. 2012;46(11):3434-3470.

9. Kayhanian M. Biodegradability of the organic fraction of municipal solidwaste in a high-solids anaerobic digester. Waste Management \& Research. 1995;13(2):123-136.

10. Ostrem K. Greening Waste: Anaerobic Digestion for Treating the Organic Fraction of Municipal Solid Wastes. Earth Engineering Center Columbia University. 2004.

11. Lokshina LY, Vavilin VA. Kinetic analysis of the key stages of low temperature methanogenesis. Ecological Model. 1999;117(2-3):285-303.

12. Britz TJ, Spangenberg G, Venter CA. Acidogenic microbial species diversity in anaerobic digesters treating different substrates. In: Proceedings of Seventh International Symposium on AD: Oral Paper Preprints, Cape Town, South Africa, 1994.
13. Fang HH, Liu H, Zhang T. Characterization of a hydrogen-producing granular sludge. Biotechnol Bioeng. 2002;78(1):44-52.

14. Ferry JG. Enzymology of one-carbon metabolism in methanogenic pathways. FEMS Microbiol Rev. 1999;23(1):13-38.

15. O'Flaherty V, Colohan S, Mulkerrins D, et al. Effect of sulphate addition on volatile fatty acid and ethanol degradation in an anaerobic hybrid reactor II: microbial interactions and toxic effects. Bioresource Technology. 1999;68(2):109-120.

16. Rinzema A. Anaerobic treatment of wastewater with high concentrations of lipid or sulphate. PhD Thesis, Wageningen Agricultural University, The Netherlands, 1998.

17. Moriarty K. Feasibility Study of Anaerobic Digestion of Food West in St. Bernard Louisiana. A study prepared in partnership with the environmental protection agency for the RE- Powering Americas land initiative: siting renewable energy on potentially contaminated land and mine sites. National Renewable Energy Laboratory (NREL), 2013.

18. Garcia JL, Patel BKC, Ollivier B. Taxonomic, Phytogenetic and Ecological Diversity of Methanogenic Archaea. Anaerobe. 2000;6(4):205-226. 